\title{
GREEN TOURISM
}

\section{Ali Hasan \\ Dosen Sekolah Tinggi Pariwisata AMPTA Yogyakarta}

\begin{abstract}
Green tourism is defined as environmentally friendly tourism activities with various focuses and meanings. In a broad term, green tourism is about being an environmentally friendly tourist or providing environmentally friendly tourist services. The green tourism concept would be highly appealing to tourism enterprises and operators owing to increasing governmental pressure to improve environmental performance by adopting effective and tangible environmental management techniques.
\end{abstract}

Green tourism is a form of tourism involving visiting fragile, pristine, and relatively undisturbed natural areas, intended as a low-impact and often small scale alternative to standard commercial tourism. Its purpose may be to educate the traveler, to provide funds for ecological conservation, to directly benefit the economic development and political empowerment of local communities, or to foster respect for different cultures and for human rights. Green Tourism has been considered a critical endeavor by environmentalists, so that future generations may experience destinations relatively untouched by human intervention.

Furthermore, achievement and promotion of internationally recognized environmental awards would be instrumental to the tourism enterprises in marketing their services. As a result, many concerned and responsible parties put forward recommendations for green tourism products to regulate tourism's negative impacts.

This conceptual paper attempts to discuss green tourism concept its processes as well explain approaches of green tourism industry can legitimately open up new areas for the more discriminating and wider range of the market, and tourists or visitors can enjoy the holiday they want with a clear conscience

Responsible green tourism programs and plans include those that minimize the negative aspects of conventional tourism on the environment and enhance the cultural integrity of local people. Therefore, in addition to evaluating environmental, social and cultural factors, an integral part of green tourism is the promotion of recycling, energy efficiency, water conservation, and creation of economic opportunities for local communities. For these reasons, green tourism often appeals to advocates of environmental and social responsibility.

Marketing people -all in public, government and private level specialists- working in tourism sector, should configure the best green solutions for the current and future strategies. The real green alternatives are needed to suggest a new perspective(re-thinking process) about tourism marketing strategies.

Keywords: Green tourism, environmentally friendly marketing, conservation, economic development, local communities and social responsibility 


\section{PENDAHULUAN}

Sejak wisatawan memperlihatkan kepedulian terhadap lingkungan, para stakeholder-pun mulai mengarahkan perhatiannya pada pemahaman kolektif tentang kebijakan dan strategi pengembangan pariwisata berbasis lingkungan, agar eksekusinya memiliki dampak yang dapat dirasakan sekarang dan dimasa-masa mendatang. Pariwisata didefinisikan sebagai perjalanan seseorang atau sekelompok orang ke luar rumah untuk memenuhi kebutuhannya. Pari-wisata juga digambarkan sebagai sistem yang mempertemukan pasar (dari sisi demand) dan daerah tujuan (daya tarik dari sisi supply). Pariwisata juga dilihat sebagai kegiatan dalam menyediakan layanan, pendapatan dan dampak ekonomi bagi provider, masyarakat destinasi, dan pemerintah. Dalam skala besar umumnya disebut sebagai pariwisata massal. Dalam beberapa tahun terakhir muncul jenis pariwisata alternatif yang secara kolektif disebut dengan istilah yang berbeda seperti phosphate free, recyclable, refillable, 'ozone friendly, 'environmentally friendly, ecotourism, sustainable tourism dan responsible tourism. Penulis sendiri cenderung menggunakan istilah Green Tourism yang spirit dasarnya dibangun dari sikap konsisten terhadap nilai-nilai sumber daya alam, sosial dan masyarakat, dimana host dan tamu dapat berinteraksi untuk menikmati dan layak berbagi pengalaman positif.

Dari sisi science, masalah terbesar dalam green tourism adalah masih terbatasnya sumber-sumber bacaan di lingkungan akademik, sementara tuntutan kepustakaan dalam hal yang sama semakin meningkat dalam perspektif yang beragam. Tulisan ini secara khusus memperkenalkan konsep green tourism dan menjelaskan secara singkat keberlanjutan eko-nomi green tourism, strategi pengembangan green tourism, alasan pentingnya green tourism, perencanaan green tourism, komunitas lokal, green tourism marketing dan peluang pasar.

Definisi dan logika ekonomi mempertegas alasan akan pentingnya penggunaan green tourism, bahwa manusia hidup di dunia memiliki sumber daya yang terbatas, dengan itu mereka harus berusaha memenuhi keinginan yang tidak terbatas. Di dalam pemasaran, pelanggan sebagai orang yang memiliki 'freedom of choice' atau kebebasan memilih, itu artinya individu, kelompok atau organisasi mempunyai hak dimana keinginan mereka harus terpenuhi. Pperusahaan yang menghadapi sumber daya alam yang terbatas, mereka harus menciptakan alternative baru dalam usaha memenuhi keinginan atau kebutuhannya. Tentunya, 'green tourism' melihat bagaimana aktivitas pariwisata dapat menggunakan sumber daya yang terbatas untuk memuaskan keinginan wisatawan, baik individu ataupun industri, serta mencapai tujuan penjualan organisasi.

Tiga cendekiawan jagad raya di tahun 2008. Thomas Friedman, Jeffrey Sachs dan Al Gore : The Common Wealth: Economics for a Hot, Flat, and Crowded - menurut mereka bumi kita sekarang ini : Hot, bumi makin panas, karena global warming terjadi perubahan yang ekstrim dari tata iklim dunia, Flat - dunia ini semakin kempes - membantu berjuta-juta orang dengan mudah melihat masalah-masalah global. Crowded bumi kita ini di huni oleh 7 miliar orang. Hot dan crowded merupakan ancaman yang harus dtangani segera dan secara bersama-sama, kita yang memerlukan ketersediaan makanan yang lebih banyak, energi, dan sumber daya terbarukan Innallaha laa yugayyiru maa biqaumin hattaa yugayyiruu maa bi an fusihiim -Sesungguhnya Allah tidak akan merobah keadaan sesuatu kaum sebelum mereka 
merobah keadaan yang ada pada diri mereka sendiri - ar Ra ad 11 - we need a green revolution - oleh karena itu :

1. pemerintah harus memaksa perusahaan untuk menjadi lebih bertanggung jawab terhadap kelestarian sumber daya lingkungan; misalnya dengan cara

a. menghentikan operasi perusahaan yang menimbulkan kerusakan lingkungan,

b. meyakinkan perusahaan bahwa semua tipe konsumen memiliki kemampuan menekan perusahaan agar kegiatan mereka ramah lingkungan, menilai komposisi kebutuhan produk lingkungan dan menolak produk yang merusak lingkungan

c. menunjukkan besarnya faktor biaya yang terkait dengan penanganan limbah

d. meyakinkan bahwa semua tipe konsumen memiliki kemampuan untuk menilai kompisisi kebutuhan produk lingkungan.

e. mengurangi produksi produk yang berbahaya, dan membatasi penggunaan konsumsi kebutuhan produk yang berbahaya

2. mendorong peningkatan penggunaan green tourism sebagai peluang untuk mencapai tujuan perusahaan, memperkuat moral - etika bisnis yang lebih bertanggung jawab terhadap lingkungan, budaya dan social (Polonsky, 2011).

\section{KONSEP GREEN TOURISM}

Green tourism mendorong keberlanjutan melalui proses selektif dalam pengembangan program pemasaran untuk menarik wisatawan yang sadar lingkungan, menunjukkan sikap respek terhadap komponen alam, mimiliki kepedulian terhadap kelestarian lingkungan dan sensitifitas budaya lokal yang dianggap sebagai model wisata yang paling baik dalam menyelamatkan sumber daya yang terbatas untuk memenuhi variasi kebutuhan baik sekarang maupun untuk generasi masa mendatang.

Green tourism itu beragam seperti desa wisata, agrowisata, guest house green, green hotel, wisata alam dan sejenisnya adalah model yang paling ideal bagi sebuah berkelanjutan pariwisata dalam menciptakan tatanan ekonomi baru (Dowling, and Fennell, 2010). Sebagai bentuk wisata alternatif, green tourism memiliki fokus pada pertimbangan kapasitas, edukasi, pelestarian sumber daya lingkungan dan pembangunan daerah, dan kegiatan khas daerah. Sebuah destinasi layak disebut sebagai green tourism jika memiliki empat dimensi utama, yaitu basis alam, dukungan konservasi, keberkelanjutan dan pendidikan lingkungan (Weaver, 2012), oleh karena itu konsep green tourism -- merupakan bentuk pariwisata yang memiliki tampilan terbaik dalam memupuk pengalaman belajar dan apresiasi secara berkelanjutan dalam mengelola dan meningkatkan kelestarian lingkungan alam, budaya, sosial, sumber daya destinasi dan mempromosikan kelangsungan hidup yang lebih berkualitas di masa-masa mendatang.

Aspek operasional konsep ini dikembangkan dengan indikatorindikator positif sebagai berikut :

1. Visi - dibangun berdasarkan semangat ekologis (pelestarian, perlin-dungan), komersial, sosial dan budaya, peningkatan kualitas sumber daya sebagai dasar pengembangan bisnis pariwisata secara berkelanjutan.

2. Differensiasi - destinasi wisata dibangun sesuai dengan kondisi 
lokalitas, gaya arsitektoral, keunikan budaya dan lingkungan hidup setempat.

3. Pengembangan (a) a trak s i tambahan bersumber dari akar budaya lokal dan dikembangkan untuk melengkapi atribut lokal, (b). layanan pengunjung yang dapat meningkatkan apresiasi wisatawan terhadap budaya lokal dan lingkungan.

4. Manajemen kinerja : dinyatakan dalam ukuran kinerja (kuantitatif dan kualitatif) : tingkat perumbuhan, melebihi daya dukung yang membahayakan lingkungan alam atau batas-batas lingkungan sosial, dan bagai-mana pengaruhnya terhadap kualitas hidup masyarakat setempat.

\section{KEBERLANJUTAN EKONOMI GREEN TOURISM}

Semua tahu bahwa munculnya pariwisata massal pada paruh kedua abad ke-20 dise-jajarkan dengan munculnya gerakan penyelamatan lingkungan global. Peningkatan jumlah wisatawan yang berkunjung ke destinasi menimbulkan dampak buruk atau kerusakan ling-kungan. Reaksi atas masalah ini di tahun1980-an muncul sebuah asosiasi dunia - world commission environment development yang secara gencar mengkampanyekan gerakan pemanfaatan sumber daya lingkungan secara berkelanjutan untuk menjamin pertumbuhan ekonomi jangka panjang. Dalam kontek pariwisata green tourism merupakan generator bagi pembangunan pariwisata berdasarkan prinsip dasar berikut ini :

1. perencanaan yang holistik diikuti dengan strategi dan program berorientasi lingkungan;
2. menekankan pentingnya proses dan kebutuhan untuk melestarikan lingkungan;

3. kebutuhan untuk melindungi warisan budaya dan keanekaragaman hayati;

4. kebutuhan untuk menumbuhkan produktivitas jangka panjang;

5. kebutuhan untuk mencapai keseimbangan antara tujuan ekonomi, lingkungan, sosial dan budaya sebagai ekuitas bangsa dan ekuitas antar bangsa-bangsa.

Intinya, secara ekonomi, green tourism memiliki kemampuan untuk memenuhi kebutuhan masa kini tanpa mengorbankan kemampuan dalam memenuhi kebutuhan generasi mendatang, konsep dasarnya dibangun berdasarkan tiga gagasan utama: Pertama, mutualsimbiosis antara pariwisata, lingkungan dan sosial berada dalam ikatan sistem yang terin-tegrasi, Kedua, kebutuhan akan kepedulian masyarakat dan keterlibatannya dalam pengem-bangan pariwisata - mereka adalah komponen sumber daya yang terkait erat dengan pari-wisata - mereka bisa merugikan pariwisata - sebaliknya, mereka bisa menjadi daya gerak kelestarian lingkungan destinasi wisata, dan Ketiga, memperkuat konsep tanggungjawab pengembangan pariwisata berkelanjutan sejalan dengan kelestarian ekologi, sosial, budaya dan ekonomi (Fennell, 2010). Dengan cara diyakini mampu memenuhi kebutuhan wisatawan dan tuan rumah sekarang sambil melindungi dan meningkatkan lingkungan, sosial dan nilai ekonomi untuk masa depan.

Pengembangan green tourism sebagai bentuk pengelolaan seluruh sumber daya sedemikian rupa sehingga dapat :

1. memenuhi kebutuhan ekonomi, sosial, estetika, menjaga integritas budaya, ekologi, biologi dan 
keanekaragaman hayati untuk mendukung sistem kehidupan yang lebih baik.

2. mengembangkan kesadaran yang lebih besar dan pemahaman yang signifikan akan kontribusi pariwisata dalam menjaga melestarikan dan meningkatkan kualitas lingkungan dan pertumbuhan ekonomi.

3. meningkatkan kualitas hidup masyarakat lokal dan mempromosikan keadilan antar generasi

4. memberikan kualitas pengalaman yang lebih baik bagi pengunjung.

Untuk mencapai ketiga tujuan itu, tindakan yang perlu dilakukan adalah konservasi sumber daya, menghindari tindakan yang mendegradasi lingkungan, mempromosikan atrakasi wisata untuk tujuan pelestarian lingkungan dan kerja sama dalam membangun pariwisata yang ramah lingkungan.

\section{STRATEGI PENGEMBANGAN GREEN TOURISM}

Pariwisata diakui sebagai kegiatan yang bersifat komposit, multiplisitas dan berefek ganda, maka kebijakan dan pengambilan keputusan nasional dan regional mestinya mengacu pada : Pertama: matriks evaluasi yang berkaitan dengan : dampak ekonomi (positif dan negatif), efek sosial (positif dan negatif), efek lingkungan (positif dan negatif), efek budaya (posistif dan negatif). Kedua : manajemen pengunjung (reguler atau MICE), ukuran, kelompok, lama tinggal, penyediaan infrastruktur, fasilitas bagi pengunjung, penyediaan informasi dan pendidikan atas aturan yang boleh dan tidak boleh dilakukan selama di destinasi. Ketiga: pilihan strategi sebagai mekanisme dan proses dimana tujuan green tourism dapat dicapai misalnya conservation strategy, lean strategy, defensive strategy, shaded strategy dan extreme strategy atau gabungannya

Paling tidak ada lima strategi pengembangan green tourism, yaitu conservation strategy, lean strategy, defensive strategy, shaded strategy dan extreme strategy yang dipandang sebagai mekanisme dan proses dimana tujuan green tourism dapat dicapai (Dowling, 2010) dan pengelolaan green tourism dilakukan melalui kegiatan manajemen : pengunjung reguler, ukuran, kelom-pok dan lama tinggal, penyediaan infrastruktur, fasilitas bagi pengunjung, penyediaan informasi dan pendidikan atas aturan yang boleh dan tidak boleh dilakukan selama di destinasi. Manajemen green tourism mencakup penggabungan sejumlah strategi seperti kode etik, akreditasi untuk menghasilkan praktek wisata terbaik.

Salah satu strategi yang disertakan dalam tulisan ini adalah strategi konservasi dengan penekanan ecodevelopment adalah konsep yang mengakui saling ketergantungan lingkungan, ekonomi dan sosial. Strategi ini merekomendasikan untuk mengambil tindakan yang menjamin pemeliharaan sumber daya wisata (alam atau buatan manusia) jangka panjang. Pariwisata memiliki ketergantungan yang kuat pada sumber daya alam yang berkualitas, oleh karena itu green tourism sebetulnya bukan hanya cita-cita yang tetapi keharusan ekonomi - ini masuk akal, karena ekonomi yang baik akan tumbuh dari kemampuan menjaga lingkungan, lingkungan sebagai sumber daya yang memberi peluang untuk digunakan para pelaku bisnis secara kompatibel. Oleh karena itu yang paling ideal adalah bahwa perencanaan pembangunan kepariwisataan harus merupakan proses yang mengintegrasikan pertimbangan ragam ekonomi, struktur lingkungan, sosial dan budaya secara 
terkendali.Tujuan dari strategi ini adalah :

1. meminimalkan erosi sumber daya dari setiap kegiatan pariwisata yang dikembangkan;

2. melindungi image destinasi sejalan dengan perlindungan lingkungan dan mengoptimalkan kepuasan pengunjung;

3. menyediakan kerangka kerja untuk meningkatkan taraf hidup masyarakat lokal melalui manfaat ekonomi dari pariwisata;

4. mengembangkan infrastruktur dan menyediakan fasilitas rekreasi bagi wisatawan dan masyarakat;

5. memastikan bahwa jenis pembangunan destinasi dan resort sesuai dengan tujuan masing-masing daerah;

6. mengintegrasikan dan mengembangkan program yang konsisten antara kehidupam sosial, budaya dan ekonomi, tuan rumah dan kepentingan pemerintah;

7. memaksimalkan perlindungan aset sumber daya lingkungan - sumber daya terbarukan.

8. melestarikan dan meningkatkan atraksi tujuan wisata yang unik untuk menjaga pariwisata sebagai kegiatan ekonomi jangka panjang. Untuk mencapai tujuan ini dilakukan dengan cara :

a. mengidentifikasi pendekatan pemasaran dan model pembangunan green tourism;

b. beradaptasi dengan faktor lingkungan eksternal yang uncontrolable;

c. menjaga keunikan produk;

d. membuat rincian tujuan pemasaran dan organisasi; e. menghindari dampak negatif yang tidak diinginkan seperti degradasi sosial, budaya dan lingkungan.

\section{PERENCANAAN GREEN TOURISM}

Kebijakan, rencana, strategi dan aksi merupakan fokus kebijakan yang mencerminkan kemauan politik lingkungan untuk kepentingan publik, yang mencakup nilai-nilai dan ideologi, distri-busi kekuasaan, kerangka kerja institusional dan proses pengambilan keputusan. Kebijakan dibuat di berbagai tingkatan, dari sekala mikro (kota/ kabupaten, propinsi) dan skala makro (nasional) dengan melibatkan berbagai kelompok yang mempengaruhi kebijakan seperti asosiasi industri pariwisata, kelompok konservasi, tokoh - kelompok masyarakat, komunitas akademisi, konsultan dan anggota parlemen yang signifikan.

Perencanaan merupakan proses prediksi (dokumen tertulis) dan karena itu memerlukan beberapa persepsi masa depan. Meskipun bergantung pada pengamatan dan deduksi penelitian sekarangjugasangatbergantung padanilainilai komunitas yang diyakini bersama. Perenca-naan harus menyediakan sumber daya untuk pengambilan keputusan dan tindakan yang diperlukan. Pertumbuhan pariwisata yang tidak terkendali dapat menghancurkan sumber alam yang tersedia atau sumber daya yang dibangun. Yang ideal adalah perencanaan pariwisata merupakan proses yang disusun berdasarkan hasil penelitian dan evaluasi untuk mengop-timalkan kontribusinya terhadap kesejahteraan manusia dan kualitas lingkungan.

Pariwisata sebagai industri global, tren pertumbuhan semakin menguat, bergerak lebih cepat dan menghasilkan revenu yang lebih tinggi, tetapi tidak 
boleh mengorbankan aspek sosial dan integritas ekologi daerah tujuan, untuk itu para pembuat kebijakan pariwisata, terutama pemerintah, dipaksa untuk mempertimbangkan berbagai pendekatan baru (misalnya informasi, regulasi, akreditasi green tourism) untuk memastikan bahwa kegiatan pariwisata, masyarakat setempat, wisatawan dan bisnis tidak menimbulkan dampak negatif terhadap lingkungan.

Kebijakan dan perencanaan yang tidak sehat, ditambah dengan kenyataan bahwa pari-wisata adalah sektor dengan pertumbuhan tercepat dan industri terbesar di dunia, lebih dari $20 \%$ dari pasar perjalanan dunia sebagai wisatawan, menunjukkan pertumbuhan ekonomi dari sektor ini di masa mendatang akan semakin dominan. Oleh karena itu kebijakan green tourism harus menjadi kesepakatan bersama dalam menseimbangkan pembangunan ekonomi vs konservasi lingkungan (peremajaan sember daya), pasokan vs permintaan, manfaat vs biaya, dan orang vs lingkungan. Faktor signifikan yang mungkin menghambat kebijakan pengembangan green tourism adalah kesepakatan tentang bagaimana mendefinisi konsep dan mengidentifikasi, proses klasifikasi produk green tourism. Tinjauan kritis terhadap green tourism (definisi, produk dan kebijakan) memberikan gambaran sejauh mana kebijakan green tourism regional dan nasional secara dinamis mensukseskan gerakan green tourism itu sendiri.

Kerangka kerja perencanaan lingkungan dan pariwisata adalah keyakinan intrinsik yang tidak hanya sebatas menjaga kelestarian budaya dan struktur sumber daya tetapi juga harus diikuti dengan aksi untuk menciptakan sumber daya terbarukan. Untuk mencapai tujuan ini, strategi perencanaan daerah, penggunaan lahan harus mencakup perlindungan sumber daya, pertanian, penggunaan bahan baku, penataan daerah perkotaan dan pertambangan harus dibentuk secara hati-hati, direncanakan dan dikendalikan untuk menentukan kondisi pertum-buhan, mempertahankan dan meningkatkan kualitas lingkungan. Fitur alam yang luar biasa akan terus menjadi signifikan sebagai tempat wisata jika mereka dilestarikan. Jika ada keraguan bahwa lingkungan alam tidak dapat dilindungi atau ditingkatkan maka pengem-bangan pariwisata seharusnya tidak diperbolehkan untuk dilanjutkan.

Perencanaan green tourism melibatkan aspek lingkungan mulai dari perlindungan, konservasi sumber daya dan penilaian dampak sementara perencanaan pariwisata terhadap lingkungan dan aspek sosial. Kebutuhan penelitian untuk perencanaan green tourism diartiku-lasikan untuk penentuan zonasi dan evaluasi dampak pariwisata. Aspek lain yang membu-tuhkan penelitian seperti wilayah bebatuan pegunungan, tanah kering dan lainya serta hubungan antara lingkungan dan aspek sosial dari pengembangan green tourism.

Salah satu aspek penting dari perencanaan green tourism adalah kebutuhan integrasi pariwisata dengan tujuan pembangunan daerah. Perencanaan pariwisata - wisata alam dan konservasi harus dikoordinasikan dan diintegrasikan di perencanaan tingkat nasional, regional dan lokal sehubungan dengan sebaran geografis dan intensitas pariwisata itu berkembang atau dikembangkan. Kompatibilitas lingkungan-pariwisata alam di daerah yang terbaik dilakukan pada tingkat regional dapat memberikan peluang terbaik untuk mencapai tujuan pelestarian lingkungan termasuk perencanaan penggunaan lahan untuk kegiatan kepariwisataan. Bisa jadi rancangan green tourism memiliki tujuan yang berbeda, akan tetapi endingnya adalah kesejahtraan masyarakat lokal, 
menjaga ekosistem dan pelestarian nilainilai sosial dan budaya setempat sepanjan jaman.

Perencanaan green tourism tingkat nasional menggabungkan ekonomi, sosial, ling-kungan, rincian kebijakan, strategi dan tahapan dengan keseluruhan tujuan perencanaan pariwisata nasional. Rencana pariwisata meliputi identifikasi atraksi utama green tourism, penetapan wilayah green tourism, akses transportasi ke dan di dalam suatu negara, dan pola ecotouring. Rencana nasional juga merekomendasikan pengembangan, desain, dan fasilitas standar dan unsurunsur kelembagaan untuk menerapkan secara efektif dan mengoperasikan green tourism. Rencana tersebut biasanya didasarkan pada proyeksi kurun waktu 5 sampai 10 tahun yang kemudian dilakukan tinjauan secara periodik.

Perencanaan green tourism tingkat regional mengidentifikasi sesuai strategi dan kebijakan daerah, akses ke semua titik wisata regional, jaringan transportasi internal, primer dan sekunder, pengembangan atribut atraksi eco-wisata, ecoresorts yang spesifik, dan pola ecotourist daerah - yang terintegrasi dengan kegiatan ekonomi, sosial dan lingkungan serta kebutuhan ruang untuk partisipasi publik dalam penyusunan rencana green tourism regional. Masalah lingkungan hidup di tingkat daerah termasuk kebutuhan zonasi yang memadai untuk mendorong konsentrasi atau penyebaran kegiatan wisata - konsentrasi melindungi lingkungan - atau penyebaran yang memungkinkan distribusi skala pengembangan seluruh wilayah dalam rangka mengurangi tekanan lingkungan di setiap destinasi, dan perencanaan green tourism tingkat regional menawarkan kesempatan dan peluang terbaik untuk mencapai pariwisata yang pro-proteksi lingkungan. Sebuah kebijakan pariwisata berwawasan ling-kungan daerah merupakan sarana mengadvokasi dan mempromosikan konservasi, strategi segmentasi pasar wisatawan yang sadar konservasi, pertumbuhan dan pemantauan perubahan.

Pada destinasi, perencanaan ecoresorts, homestay dan fasilitas terkait seperti analisis lokasional, kelayakan finansial, penilaian lingkungan dan perencanaan situs yang menggabungkan lingkungan dengan sensitif arsitektur wisata, rekayasa desain dan lansekap. Eco-ethics mendorong desain lingkungan untuk bersesuaian dengan sensitifitas wisata alam sementara ecolodges menekankan tingkat kreatifitas dan interaksi positif dengan fitur alami. Konsep ini mengharuskan pemerintah, operator wisata, fasilitas green tourism, dan empati antara host dan wisatawan harus dibina, suasana dipelihara dan ditingkatkan dalam hubungan yang harmonis (Ginsberg, et al, 2012)

\section{KOMUNITAS LOKAL}

Mungkin manfaat yang paling menonjol dari kebijakan dan perencanaan green tourism adalah untuk mendorong perkembangan yang memberikan manfaat bagi komunitas lokal dan lingkungan alam masyarakat setempat. Peluang pekerjaan baru, bisnis dan penghasilan tam-bahan, pasar baru untuk produk lokal; perbaikan infrastruktur, pelayanan masyarakat, fasi-litas; keterampilan dan teknologi baru; meningkatkan kesadaran budaya dan lingkungan, kon-servasi dan perlindungan, dan meningkatkan penggunaan lahan. Green tourism pada tingkat masyarakat dikembangkan secara berkelanjutan dalam konteks regional, nasional bahkan internasional, dengan mengacu pada prinsip-prinsip :

a. Keberlanjutan ekologis yang menjamin kompatible pembangunan ekonomi dengan proses pemeliharaan 
ekologi, keragaman biological dan sumber daya hayati.

b. Keberlanjutan sosial dan budaya yang menjamin peningkatan pembangunan kehidupan masyarakat setempat, kompatibel dengan budaya dan nilai-nilai, memelihara dan memperkuat identitas masyarakat.

c. Keberlanjutan ekonomi yang menjamin peningkatan pembangunan yang sumber daya ekonomi yang efisien untuk mendukung keberdayaan generasi mendatang.

Green tourism memberikan kesempatan untuk mempresentasikan sifat alamiah suatu daerah, mempromosikan sebuah identitas yang unik, membuat pengalaman wisata yang me-narik, mempromosikan keunggulan pariwisata, hadir melindungi alam dan manfaat bagi ma-syarakat lokal, mendorong sukses secara komersial dan operasi lingkungan wisata yang baru.

Kontribusi potensial yang ditawarkan green tourism adalah kemampuan memaksi-malkan peluang dan minghilangkan atau paling tidak meminimilkan dampak negatif terhadap lingkungan. Jika hal ini dilakukan maka basis voice green tourism berkembang dalam pengaturan mutual-simbiosis dengan lingkungan alam, sosial dan budaya.

\section{GREEN TOURISM MARKETING}

Dalam pemasaran, produk apapun yang ditawarkan, endingnya tetap sama yaitu kepuasan pelanggan, keuntungan, retensi pelanggan dan keberlanjutan untuk jangka panjang. Pemasaran pariwisatapun tidak pernah lepas dari empat kepentingan itu. Oleh karena itu nilai sebuah keberlanjutan dalam pemasaran pariwisata adalah totalitas system perencanaan harga, promosi, dan produk pasar yang spesifik untuk memuaskan wisatawan (pengalaman positif) yang memiliki manfaat sosial dan ekonomi bagi masyarakat dan keuntugan bagi perusahaan secara berkelanjutan tanpa mengorbankan sumber daya alam, Laa tufsiduu fil ardhi ba'da ish-laa hi haa - Janganlah kamu membuat kerusakan di muka bumi sesudah Tuhan-mu menciptakan dan memperbaikinya - al A'raaf : 56, 85

- haram hukumnya merusak lingkungan (Fahmi Hamdi, 2012). "green tourism markting is a total process activities and outcome arising designed to plan, price, promote, and make available to selected markets products and services in the form of benefits and experiences that create satisfied guests and achieve organizational objectives from the relationship and the intraction among the tourist, tourism supplier, host government, host communities, surrounding and sustainable environment that are involved in the attracting and hosting visitors" (Hsu, et al, 2012),

Model green tourism marketing berorientasi aspek ekonomi, sosial dan lingkungan (gambar 1) harus dilakukan secara terpadu untuk memenuhi semua kepentingan stakeholder yang terlibat dalam pariwisata. Dengan demikian kemampuan mendesign kesesuaian produk, harga dan promosi adalah langkah awal yang sangat penting dalam mengantisipasi dan memuaskan keinginan wisatawan yang ada dan calon pengunjung secara lebih efektif dari pemasok lain (pesaing). Perubahan perencanaan akan dipacu oleh keuntungan dan manfaat bagi pengunjung, masyarakat dan lingkungan secara simultan. Sukses perusahaan dalam jangka panjang tergantung interaksi antara guests, provider dan pemasok. Memenuhi kepuasan guests, menyelamatkan kondisi lingkungan dan kebutuhan masyarakat merupakan inti 
dari green tourism marketing.

Pengelolaan dan kegiatan pemasaran harus dimulai dari political will pemerintah se-bagai otoritas pengembangan green tourism yang didukung oleh peran serta masyarakat dalam membuka usaha-usaha yang berkaitan dengan kepariwisataan seperti hotel, tempat hiburan, usaha toko suvenir dan makanan, retaurant dan jasajasa yang lain. Pihak pemerintah mempunyai kewenangan manajerial dan promosi serta masyarakat mensupportnya.

Dalam pelaksanaannya harus dilakukan dalam kerangka pemberdayaan segala potensi yang dimiliki untuk tujuan wisata yang berakhir pada peningkatan kesejahteraan, berdasarkan paradigma (1) revitalisasi dan konservasi lingkungan, (2) revitalisasi dan konservasi sejarah dan budaya, (3) pemberdayaan masyarakat. Pembangunan kawasan wisata baru harus men-cermati kepentingan pelestarian lingkungan dan memperhatikan tata ruang yang diundangkan dalam peraturan daerah tempat destinasi dikembangkan.

Peninggalan sejarah dan budaya perlu dilindungi peraturan daerah, dengan upaya mere-vitalisasi - renovasi, dan upayaupaya pelestarian. Sementara usaha mikro masyarakat dapat dikembangkan dengan berbagai kemudahan mendapatkan kredit usaha yang mendukung pariwisata. Realisasi program wisata akan dikembangkan melalui (a) diversifikasi, (b) daya tarik, dan (c) keterpaduan paket wisata. Diversifikasi didasarkan atas asumsi-asumsi yang melahirkan postulat, metode, teknik dan strategi-strategi pengembangan wisata terpadu.

Di kawasan wisata tertentu yang memiliki pesona alam yang indah, secara terpadu dapat di-diversifikasi melalui tujuan wisata misalnya olah raga, konservasi budaya masyatakat, kawasan pendidikan, layanan sosial, tempat rekreatif seperti taman pintar di Jogjakarta berikut plaza-plaza - pusat perbelanjaan, paket wisata jalan kaki, paket wisata naik sepeda, paket wisata menunggang kuda, paket wisata all terrain vehicle, dan sebagainya. Semuanya harus selaras dengan rencana tata ruang wilayah yang dikembangkan.

Pengembangan wisata ritual dan keagamaan dengan potensi bangunan tempat ibadah di yang indah dan harus diisi dengan kegiatan-kegiatan keagamaan dan ritual lainya. Demikian juga dengan daya tarik periwisata tergantung pada pengelolaan dan bagaimana sinergitas dengan lingkungan sekitar. Kebersihan, layanan keamanan, layanan parkir, prinsip harmoni dan keselarasan antara fisik dan non fisik, serta daya tarik atraksi budaya yang disajikan.

Keterpaduan merupakan hal utama yang dikonsepkan agar pembangunan green tourism merupakan satu kesatuan yang saling menunjang secara resiprokalitas. Misalnya saja DIY dengan lima otoritas pemerintahan yang masingmasing mengembangkan 5-10 destinasi wisata unggulan - mungkin lama tinggal di Yogyakarta bisa menjadi $5-6$ hari.

Keterlibatan lintas sektor - keterkaitan lintas sektor dalam sistem pemerintahan seha-rusnya memiliki peran dominan dalam proses inisiasi dan pengelolaan destinasi wisata yang didukung oleh komunitas, pelaku pariwisata, badan pengelola sejarah maupun kelompokkelompok budaya - adat setempat untuk menciptakan keamanan dan kenyamanan bagi wisatawan maupun masyarakat pada umumnya. Demikian juga daya dukung fasilitas seperti infrastruktur jalan, moda transfortasi, perbankan (ATM misalnya) dan money changer meru-pakan bagian yang mutlak diperlukan untuk mendukung suksesnya pariwisata - green tourism itu sendiri. 


\section{PELUANG PASAR}

Secara konseptual tidak kurang dari 53 aspek yang umumnya digunakan dalam memprediksi kemungkinan perusahaan - produk untuk berhasil. Satu diantaranya adalah aspek pasar. Pasar dimaknai dalam kontek para pembeli tawaran pasar baik aktual maupun potensial. Produk green tourism bukan untuk pasar masal, ia menjadi peluang untuk wisa-tawan individu, kelompok atau organisasi yang memperhatikan lingkungan, itu sebabnya seg-mentasi pasar menjadi penting. Segmentasi pasar adalah proses membagi pasar kedalam unit-unit yang mudah diukur dan dapat dijangkau (Ali Hasan, 2013) misalnya daerah - negara asal wisatawan nusantara dan mancanegara yang berkunjung ke suatu daerah tujuan wisata di Indonesia. Unit-unit tersebut dalam kontek pariwisata dapat berupa negara, provinsi, kota, kabupaten, dan kecamatan. Dalam hal yang sama diasumsikan bahwa proksimitas (kedekatan wilayah) berperan penting dalam pengambilan keputusan. Kedekatan wilayah menyebabkan kesamaan selera dan kemudahan akses ke penyedia jasa. Untuk wisatawan mancanegara, ka-rakteristik negara asal seringkali cukup kuat sebagai faktor pembeda dalam memilih destinasi. Kecenderungan wisatawan dunia terhadap green tourism sebagai berikut :

1. Riset di 16 negara mencatat bahwa lebih dari $50 \%$ wisatawan di setiap negara sebagai wisatawan green, tren sosial, green economic, dan ekologi. Terlebih di Singapura mena-ruh perhatian terhadap limgklungan. di Australia ditemukan 84,6\% individu memiliki tanggung jawab untuk menjaga lingkungannya. Lebih lanjut, $80 \%$ mengubah perilakunya termasuk perilaku dalam pembelian untuk alasan lingkungan (Grundey, and Zaharia, 2011)

2. Meningkatnya kekhawatiran akan keselamatan

a. $83 \%$ wisatawan Inggris yang berwisata dalam paket wisata mengatakan bahwa pantai yang kotor dan laut yang terpolusi oleh limbah menjadi pertimbangan utama dalam memilih destinasi. $74 \%$ sangat dipengaruhi oleh tingkat kriminalitas (ber-kaitan dengan keselamatan), $62 \%$ dipenaruhi oleh tingkat epidemi di destinasi yang akan dipilih.

b. $60 \%$ dari wisatawan Jerman sangat mempedulikan sampah, $51 \%$ sangat mempe-dulikan tingkat kebisingan, dan $46 \%$ tentang proteksi alam di destinasi.

3. Ketertarikan pada pengalaman yang beragam

a. $61 \%$ wisatawan AS mencari pengalaman berwisata yang meliputi lingkungan alam dan situs budaya dan sejarah yang terperlihara dengan baik. 53\% setuju bahwa kualitas pengalaman berwisata meningkat jika mereka bisa belajar tradisi, budaya, dan lingkungan di destinasi.

b. Tiga dari empat wisatawan Inggris sepakat bahwa perjalanan mereka seharusnya mengandung pengalaman terhadap budaya dan kuliner lokal.

4. Kepedulian terhadap dampak aktivitas wisata

a. Tiga perempat wisatawan AS merasa kunjungan mereka tidak seharusnya merusak lingkungan. 
b. $59 \%$ wisatwan wanita AS menempatkan lingkungan sebagai basis produk green product, dan mereka merekomendasikan kepada orang lain untuk back to green, dan mengunjungi kembali perusahaan yang peduli lingkungan.

c. $80 \%$ dari keputusan pembelian konsumen dipengaruhi oleh dampak produk terhadap keselamatan lingkungan - green product adalah cara untuk menikmati hidup

d. $51 \%$ wisatawan Inggris menyatakan bahwa masalah kekurangan makanan dan air bersih yang dialami masyarakat lokal di destinasi sangat mempengaruhi keputusan untuk mengunjungi destinasi tersebut.

e. $65 \%$ wisatawan Inggris menyatakan bahwa reputasi perusahaan perjalanan yang berkaitan dengan isu lingkungan adalah 'penting'.

f. $82 \%$ wisatawan Belanda percaya bahwa mengintegrasikan informasi tentang upaya perlindungan lingkungan ke dalam brosur wisata adalah 'ide yang bagus'.

5. Kemauan wisatawan Inggris untuk membayar lebih

a. 53\% siap membayar lebih untuk paket perjalanan mereka jika para pekerja di destinasi terjamin upah \& kondisi tempat kerja mereka.

b. $45 \%$ siap untuk membayar lebih untuk mendukung upaya konservasi lingkungan atau untuk mengatasi kerusakan lingkungan yang terjadi di destinasi

6. lebih dari setengah masyarakat AS dewasa mengatakan bahwa mereka akan lebih suka memilih maskapai penerbangan, menginap di hotel, dan menyewa mobil yang menggu-nakan produk-produk natural. Sebanyak 58,5 juta orang mengatakan bahwa mereka bersedia membayar lebih untuk perusahaan perjalanan yang berupaya melindungi dan melestarikan lingkungan.

7. seperlima dari 26,8 juta orang Amerika yang menempuh perjalanan ke luar negeri selalu mengunjungi Taman Nasional atau melakukan aktivitas di lingkungan alam (mengunjungi Taman Nasional 9\%; hiking-5\%; skii - 2\%).

8. segmen LOHAS (Lifestyles of Health and Sustainability) di AS menyatakan bahwa ecotourism, green tourism, dan sustainable travel adalah tren wisata yang tumbuh paling cepat, pasarnya mencapai \$77 miliar. 5\% dari keseluruhan pasar perjalanan di AS.

9. lebih dari 55 juta wisatawan AS adalah 'geotourists' atau wisatawan yang tertarik pada alam, budaya, dan warisan sejarah.

10. $34 \%$ orang Eropa mencari produk 'hijau'. dan 32\% dan 1.040 responden di AS mencari dan membeli produk hijau dan tren ini setiap tahun meningkat tidak kurang dari $2 \%$. (Hong and Kim, 2012).

Hasil kajian empiris tersebut menunjukan fakta penting tentang adanya perubahan per-mintaan dalam berwisata dan pertumbuhan yang memperbesar target pasar. Bagi pecandu bisnis pariwisata melihat perubahan ini sebagai peluang - kesempatan untuk 
mengembangkan industri pariwisata model green tourism dalam mempertebal wallet share jangka panjang.

Diluar industri pariwisata, kebutuhan pemasaran dengan karakteristik lingkungan akan memiliki keuntungan lebih dibanding pemasaran yang bukan berbasis lingkungan. Beberapa contoh perusahaan yang menerapkan tanggung jawab terhadap lingkungan dalam memenuhi kebutuhan konsumen dengan lebih baik, misalnya :

1. Mcdonald mengganti kemasan dengan kertas lilin karena kekhawatiran konsumen meningkat terkait produksi polystyrene dan penipisan ozon;

2. Produsen tuna mengubah teknik memancing mereka karena kekhawatiran meningkatnya driftnet memancing, dan kematian lumbalumba

3. Xerox memperkenalkan "kualitas tinggi" kertas fotokopi daur ulang dalam upaya memenuhi tuntutan perusahaan untuk produk yang berbahaya bagi lingkungan

\section{KESIMPULAN}

Green tourism adalah sustainable tourism yang memperhitungkan kebutuhan ling-kungan, masyarakat setempat, bisnis, dan pengunjung sekarang dan di masa depan. Konsep ini relevan untuk setiap perusahaan pariwisata, besar atau kecil, pedesaan atau perkotaan, apakah berfokus pada ekowisata, usaha pariwisata dan lainnya. Pebisnis green tourism adalah mereka yang aktif terlibat dalam mengurangi dampak lingkungan dan sosial yang negatif dari kegiatan pariwisata mereka. Kurangnya pertimbangan "kehijauan", kegiatan dapat mengaki-batkan perusahaan membuat klaim palsu atau menyesatkan konsumen dalam upaya untuk meraih pasar - yang pada akhirnya perusahaan akan kehilangan pelanggan.

Analisis terhadap 1600 lebih rencana green tourism menunjukkan bahwa: (1) sepertiga darinya tidak diimplementasikan, (2) beberapa rencana pariwisata terintegrasi dengan masalah sosial, pembangunan ekonomi sebagai prioritas profitabilitas perusahaan, (3) beberapa dian-tara secara tegas dan spesifik menyatakan untuk melindungi lingkungan, dan (4) beberapa diantaranya yang sudah beroperasi antara 2 - 3 tahun kemudian off (Dowling, 2010).

Bagaimana dengan kita ?, akan tetapi ketika kita membuat keputusan memilih green tourism sebagai kegiatan pariwisata, itulah sebetulnya komitmen untuk mendistribusikan sumber daya yang kita miliki sekarang untuk kesejahtraan generasi kita di masa yang akan datang. Kita tidak boleh egois, menguras sumber daya alam, anak cucu kita dapat apa fondasinya knowledge and technological based, paradigmanya : resource based, social based and culture based economic development - demikian juga ketika kita berpikir dari sisi price, green tourism mensyaratkan, wisatawan yang menginginkan pemeliharaan lingkungan yang bersih mereka bersedia untuk 'membayar' lebih untuk itu, ini mutlak memerlukan intervensi pemerintah untuk memimpin revolusi green tourism di negeri ini.

Peningkatan jumlah pelaku yang beroperasi di pasar dan dukungan kemajuan teknologi yang pesat menyebabkan green tourism memasuki tahapan global, sejalan dengan peningkatan ekonomi global, perusahaan disamping terus berupaya memusatkan perhatian pada pemenuhan kebutuhan wisatawan lokal dan untuk dapat bertahan - bersaing, manajemen - marketer harus 
mengidentifikasi kesempatan, celah pasar baru, dan kerja sama dengan pemain lain untuk menarik dan melayani wisatawan mancanegara yang memiliki karakteristik yang cocok dengan green tourism. Perusahaan yang berhasil di pasar global adalah mereka yang mengambil fokus berfikir strategis dalam memanfaatkan teknologi sebagai tool pemasaran untuk menjangkau pasar wisatawan di seluruh penjuru jagad raya ini.

Wisatawan memiliki kemampuan untuk menekan pemasok untuk mengubah kegiatan mereka agar organisasi berkomitmen terhadap lingkungan, tidak hanya memproduksi produk yang mengurangi dampak merugikan lingkungan, tetapi juga untuk berperilaku dengan cara yang lebih ramah lingkungan dan bertanggung jawab. Dengan mengintegrasikan lingkungan ke dalam perilaku perusahaan dapat dipastikan bahwa semua kegiatan bisnis pariwisata dapat meminimalkan dampak yang merugikan lingkungan.

\section{DAFTAR PUSTAKA}

Ali Hasan, 2012. Tourism Marketing (Diktat). Yogyakarta:

Sekolah Tinggi Pariwisata AMPTA Yogyakarta. hlm $28-31$

Ali Hasan, 2013. Marketing dan KasusKasus Pilihan. Yogyakarta: Center for Academic Publishing Service. hlm 242-266

Dowling, R. K. 2010. Tourism's Emerging Global Interaction. Journal of the Geography Teachers' Association . 38 (2): pp 1923.

Dowling, R.K. 2010. Emerging tourism: Sustainable geo-resources for leisure and recreation.
Journal of Tourism.10 (1): pp 209-220.

Dowling, R.K. and Fennell, D.A. 2010. The Context of Tourism Policy and Planning. $C A B$ International Journal. pp $1-20$

Fahmi Hamdi, 2012. Fikih Lingkungan Dalam Perpektif Islam: Sebuah Pengantar. Pimpinan Wilayah $\mathrm{M} \mathrm{uh}$ a m m a d i y a h Kalimantan Selatan. 25 September 2012.

Fennell, D.A. 2010. A Content Analysis of Ecotourism. Current Issues in Tourism, 4(5) pp $403-421$

Ginsberg, J. M., Bloom, P,N., Newsome, D., Moore, S.A., and Dowling, R.K. 2012. Natural Tourism: Impacts Strategy and Mangement. Channel View Publications. pp $28-45$

Grundey, D. and Zaharia, R. M. 2011. Sustainable marketing and strategic greening. Journal Sustainability, 14(2), 130 -143 .

Hsu, Cathy H. C, Killion, L, Brown, G, Gross, M \& Huang, S 2012, Tourism marketing: an Asia-Pacific perspective. International Journal of Culture, Tourism and Hospitality Research. Vol. 16. No. 2(12): pp 54-67

Hong, S., Kim, S., \& Kim, J. 2012. Implications of Potential Green Tourism Development. Annals of Tourism Research. 30(2), 323-341. 
Polonsky, Michael, Jay. 2011. An Introduction To Green

Weaver, D. 2012. Ecotourism. Australia : Marketing. Electronic John Wiley \& Sons. p 15

Green Journal, 12(5): pp 44-53

Gambar 1. Model Green Tourism Marketing (Ali Hasan, 2012)

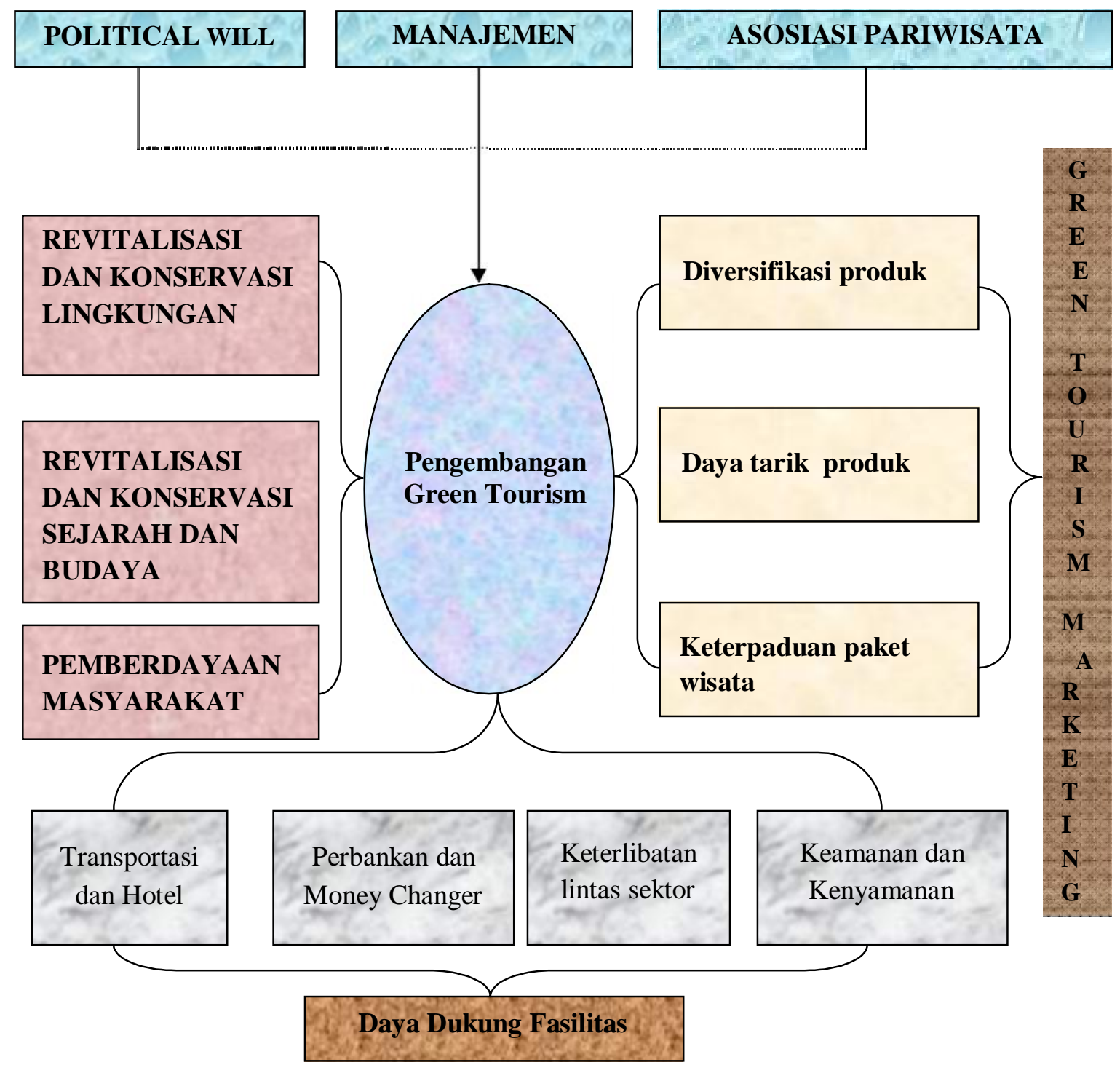

